\title{
PERAN SERTA DESAADAT DALAM PENGELOLAAN SAMPAH DI KOTA DENPASAR
}

\author{
Oleh \\ Ida Bagus Sudarma Putra \\ I Made Sudharma
}

\begin{abstract}
ABSTRAK
Masalah sampah saat ini merupakan fenomena sosial yang perlu mendapat perhatian dari semua pihak, karena setiap manusia pasti memproduksi sampah. Pemerintah kota Denpasar, tampaknya sangat menyadari kondisi tersebut sehingga dipandang perlu adanya suatu sistem dan peran pengelolaan sampah dari hulu yaitu pengelolaan yang dilakukan sedekat mungkin dengan sumbernya, hal ini dilakukan agar pengurangan, penanganan, dan penegakan hukum terhadap pengelolaan sampah dapat berjalan disatuan terkecil masyarakat secara desentralisasi. Oleh karena itu dibutuhkannya peran serta desa adat dalam pengelolaan sampah di kota Denpasar untuk melakukan pengawasan, pembinaan, dan penegakan hukum melalui pembentukan suatu aturan hukumnya sendiri berupa awig-awig atau perarem untuk mengatur hak dan kewajiban masyarakat (krama desa, krama tamiu, tamiu, serta badan usaha yang berada dalam wilayah desa adat tersebut). Berdasarkan latar belakang tersebut, maka permasalahan yang dibahas dalam penelitian ini sebagai berikut: 1) Bagaimana sistem pengelolaan sampah di kota Denpasar? dan 2) Bagaimana peran serta desa adat dalam pengelolaan sampah di kota Denpasar?. Metode penelitian yang digunakan adalah jenis penelitian empiris, sifat penelitian bersifat deskriptif, bentuk data kualitatif dan kuantitatif, , pengumpulan data menggunakan metode observasi, wawancara, studi kepustakaan, penentuan informan penelitian menggunakan teknik purposive sampling, instrument penelitian mengunakan pedoman wawancara dilengkapi dengan handphone, camera digital, pencatatan, dan dengan analisis data deskriptif kualitatif. Belum efektifnya peran serta desa adat dalam pengelolaan sampah di kota Denpasar karena 1) masih sedikitnya keberadaan fasilitas pengelolaan sampah seperti swakelola sampah, TPST 3R, TPS 3R, dan Bank Sampah yang dimiliki dan berada dibawah pengelolaan desa adat, 2) Masih rendahnya kesadaran masyarakat untuk melakukan pengelolaan sampah dari ruang lingkup keluarga atau rumah tangga sendiri, 3) Belum semua desa adat yang ada di kota Denpasar memiliki aturan dalam bentuk awig-awig atau perarem yang secara khusus mengatur hak dan kewajiban masyarakat (krama desa, krama tamiu, tamiu, serta badan usaha yang berada dalam wilayah desa adat tersebut). ,4) Kurangnya pelaksanaan pengelolaan sampah yang diwujudkan melalui sosialisasi ke setiap banjar.
\end{abstract}

\section{Kata Kunci : Desa Adat, Kota Denpasar, Pengelolaan Sampah.}

\section{PENDAHULUAN}

\section{Latar Belakang}

Masalah sampah saat ini merupakan fenomena sosial yang perlu mendapat perhatian dari semua pihak, karena setiap manusia pasti memproduksi sampah.Sampah adalah sisa kegiatan sehari-hari manusia dan/atau proses alam yang berbentuk padat. Sedangkan menurut Kamus Besar Bahasa Indonesia (KBBI, 2008, hlm. 1255)

"sampah adalah barang yang dibuang karena tidak terpakai lagi atau tidak diinginkan lagi".

Masalah sampah terjadi karena besarnya timbunan sampah. "Besarnya timbunan sampah yang tidak dapat ditangani tersebut akan menyebabkan berbagai permasalahan yang timbul akibat kurangnya alternatif dan perspektif 
masyarakat terhadap pengelolaan dan pemanfaatan sampah, baik langsung maupun tidak langsung" (Cecep Dani Sucipto, 2012, hlm. 1). Pertambahan jumlah penduduk, perubahan pola konsumsi, dan gaya hidup masyarakat juga telah meningkatkan kualitas dan kuantitas jumlah timbulan sampah, jenis, dan keberagaman karakteristik sampah. Meningkatnya volume sampah tersebut memerlukan pengelolaan sampai sesuai dengan peraturan perundang-undangan yang berlaku.

Penumpukan sampah dengan membuang atau membakarnya secara sembarangan ke kawasan terbuka akan mengakibatkan pencemaran air, tanah, dan udara. Kondisi ini diperparah dengan pola hidup masyarakat yang instan serta minimnya pandangan masyarakat terhadap pola hidup sehat, dan pada paradigma masyarakat yang masih menganggap sampah sebagai sesuatu yang harus dibuang dan disingkirkan.

Permasalahan seperti yang dijelaskan diatas juga terjadi di kota Denpasar yang merupakan ibukota dari provinsi Bali yang di kenal dengan pertumbuhan industri baik dengan sekala besar maupun kecil serta di bidang pariwisatanya. Keadaan tersebut mendorong kota Denpasar menjadi pusat kegiatan bisnis, pusat perkantoran, dan menempatkan kota ini sebagai daerah yang memiliki pendapatan per kapita dan pertumbuhan paling tinggi di provinsi Bali. Keadaan tersebut menyebabkan bertambahnya volume sampah yang ada di kota Denpasar.

Berdasarkan data dari DLHK kota Denpasar bahwa 1 orang mampu menghasilkan sampah sebanyak 4 liter dalam sehari dan produksi sampah per hari kota Denpasar setiap tahun juga mengalami peningkatan yaitu pada tahun 2016 jumlah sampah perhari mencapai 3.590,44 $\mathrm{m}^{3}$, tahun 2017 mencapai $3.657,2 \mathrm{~m}^{3}$, dan tahun 2018 mencapai $3.722,4 \mathrm{~m}^{3}$. Peningkatan ini dikarenakan laju produksi sampah terus meningkat, tidak saja sejajar dengan laju pertumbuhan penduduk tetapi juga sejalan dengan meningkatnya pola konsumsi masyarakat.
Permasalahan lain adalah rendahnya kesadaran masyarakat kota Denpasar dalam pengelolaan sampah, hal tersebut dibuktikan dengan meningkatannya pengaduan online melalui apklikasi ProDenpasar setiap tahunnya yaitu di tahun 2016 ada 188 laporan dengan rata-rata setiap bulan ada 15 laporan pengaduan, tahun 2017 ada 100 laporan dengan rata-rata setiap bulan ada 8 laporan pengaduan, dan tahun 2018 ada 120 laporan dengan rata-rata setiap bulan ada 10 laporan pengaduan dan terakhir sampai tanggal 14 Juni 2019 ada 55 laporan pengaduan. Laporan pengaduan tersebut mulai dari membuang sampah sembarang seperti dipinggir jalan, diatas trotoar, lahan kosong, sungai, membakar sampah, got tersumbat karena sampah, sungai kotor dipenuhi sampah, bau TPA dan TPS, pengambilan sampah yang tidak tepat waktu atau tidak diambil oleh petugas, info pembuangan sampah, info bank sampah, info peraturan tentang sampah sampai dengan mohon sidak.

Pemerintah kota Denpasar, tampaknya sangat menyadari kondisi tersebut sehingga dipandang perlu adanya suatu sistem pengelolaan sampah dari hulu yaitu pengelolaan yang dilakukan sedekat mungkin dengan sumbernya hal ini dilakukan agar pengurangan, penanganan, dan penegakan hukum terhadap pengelolaan sampah dapat berjalan disatuan terkecil masyarakat secara desentralisasi dengan tujuan bahwa pengelolaan sampah dapat diatur secara mandiri oleh desa adat melalui pengawasan dan pembinaan secara efektif dan efesien, namun tetap berkordinasi dengan DLHK Kota Denpasar sebagai instansi yang berwenang dalam pengelolaaan sampah.

Apalagi Pengelolaan sampah dari hulu juga didorong oleh dasar hukum yaitu Peraturan Daerah Kota Denpasar Nomor 3 Tahun 2015 Tentang Pengelolaan Sampah, dimana dalam pengelolaan sampah memberikan ruang kepada desa adat yang ada di kota Denpasar untuk berperan serta dalam pengelolaan sampah dengan melaksanakan pengelolaan sampah diwilayahnya secara mandiri dan/atau bekerjasama dengan pemerintah kota atau pihak lain sehingga menciptakan pengelolaan sampah secara desentralisasi maksudnya 
menciptakan pengelolaan sampah dari hulu atau sumber sampah pertama sehingga sampah yang masuk ke hilir atau TPAdapat berkurang dan hanya meninggalkan residunya saja.

Berdasarkan dengan adanya permasalahan yang telah diuraikan diatas tersebut, maka yang akan dibahas dalam penelitian ini adalah; 1) Bagaimana sistem pengelolaan sampah di kota Denpasar? 2) Bagaimana peran serta desa adat dalam pengelolaan sampah di kota Denpasar?

\section{METODE PENELITIAN}

Istilah metodelogi berasal dari kata "metode yang berarti jalan, namun demikian, menurut kebiasaan metode dirumuskan dengan kemungkinan-kemungkinan suatu tipe yang dipergunakan dalam penelitian dan penilaian" (Soerjono Soekanto, 2012, hlm.5).

Sedangkan Narbuko, Cholid dan Abu Achmadi (2003) dalam bukunya metodologi penelitian menjelaskan bahwa metode penelitian adalah "cara melakukan sesuatu dengan menggunakan pikiran secara seksama untuk mencapai suatu tujuan dengan cara mencari, mencatat, merumuskan, dan menganalisis sampai menyusun laporan".

Penelitian yang menggunakan metode penelitian hukum dengan aspek yuridis empiris, sifat penelitian bersifat deskriptif, bentuk data kualitatif dan kuantitatif, sumber data primer (berupa observasi dan wawancara) serta data sekunder (berupa bahan hukum primer, sekunder, dan tersier). Pengumpulan data menggunakan metode observasi, wawancara, studi kepustakaan, penentuan informan penelitian menggunakan teknik purposive sampling, instrument penelitian mengunakan pedoman wawancara dilengkapi dengan handphone, camera digital, pencatatan, dan dengan analisis data deskriptif kualitatif.

\section{HASIL PENELITIAN}

\section{Sistem Pengeloaan Sampah di Kota Denpasar}

Sistem pengelolaan sampah di kota Denpasar sangat diperlukan untuk membantu pengelolaan sampah di kota Denpasar yang semakin tahun semakin meningkat. Pada tahun 2016 dengan jumlah penduduk 897.300 jiwa menghasilkan volume sampah perhari yaitu 3.590,44 m3. Pada tahun 2017 dengan jumlah penduduk 914.300 jiwa menghasilkan volume sampah perhari yaitu 3.657,2 m3, dan Pada tahun 2018 dengan jumlah penduduk 930.600 jiwa menghasilkan volume sampah perhari yaitu $3.722,4 \mathrm{~m} 3$. Kecamatan yang paling banyak menghasilkan sampah dari tahun 2016-2018 adalah kecamatan Denpasar Selatan dan kecamatan terendah menghasilkan sampah adalah kecamatan Denpasar Timur.

Berdasarkan data dari DLHK kota Denpasar bahwa sumber sampah kota Denpasar 90\% merupakan sampah yang berasal dari rumah tangga dengan komposisi sampah yang dihasilkan oleh kota Denpasar adalah 70\% merupakan sampah organik dan 30\% merupakan sampah anorganik, dari 30\% sampah anorganik tersebut 5-15\% merupakan sampah plastik.

Melihat sumber sampah kota Denpasar yang paling banyak berasal dari rumah tangga dan rendahnya kesadaran masyarakat untuk bertanggung jawab atas sampah yang mereka hasilkan, hal tersebut melatarbelakangi kota Denpasar pada saat ini menerapkan sistem pengelolaan sampah PESAN MAMA (Sistem Pengelolaan Sampah Secara Mandiri Berbasis Masyarakat) dengan mengacu pada paradigma baru dalam sistem pengelolaan sampah yang berkelanjutan dengan prinsip pengelolaan sampah 3R (reduce, reuse, dan recycle) yang pada intinya memandang sampah sebagai sumber daya yang mempunyai nilai ekonomi dan dapat dimanfaatkan misalnya, untuk energi, kompos, pupuk ataupun untuk bahan baku industri dengan fasilitas pengelolaan sampah seperti swakelola sampah, TPST 3R, TPS 3R, dan bank sampah.

Sistem pengelolaan ini juga didasari yaitu pertama adalah dengan asas-asas pengelolaan sebagaimana dimaksud pasal 3 Peraturan Daerah Kota Denpasar Nomor 3 Tahun 2015Tentang Pengelolaan Sampah terdiri yang dari 9 asas yaitu "asas tanggung jawab, asas berkelanjutan, asas 
manfaat, asas keadilan, asas kesadaran, asas kebersamaan, asas keselamatan, asas keamanan, dan asas nilai ekonomi".

Kedua adalah manajemen pengelolaan sampah di kota Denpasar terdiri dari 5 bagian yaitu: 1). Adanya lembaga pengelolaan sampah yang berwenang dalam pengelolaan sampah di kota Denpasar yaitu DLHK (Dinas Lingkungan Hidup Dan Kebersihan) kota Denpasar dengan tupoksi (tugas pokok dan fungsi yang ada), 2). Adanya regulasi seperti undang-undang, perda, perwali, surat keputusan, dan lain-lain. 3). Adanya teknis operasional. 4). Adanya anggaran terdiri dari dana APBN yaitu Dana Alokasi Khusus (DAK), APBD, dan dana desa yaitu Akolasi Dana Desa (ADD), dan 5). Peran serta masyarakat dalam pengelolaan sampah.

Oleh karena itu DLHK kota Denpasar dalam menjalankan sistem pengelolaan sampah memiliki yang namanya DOA (Dana, Orang, dan Alat), dengan penjelasan sebagai berikut: 1). Dana dalam pengelolaan sampah di kota Denpasar diperoleh dari APBN yaitu DAK (Dana Alokasi Khusus) dan APBD kota Denpasar, 2). Orang yaitu SDM atau tenaga kerja untuk membantu menjalan sistem pengelolaan sampah di Kota Denpasar, saat ini tenaga kerja yang dimiliki kota Denpasar dibawah DLHK kota Denpasar pada Tahun 2019 mencapai 1371 orang, dan 3). Alat yaitu sarana prasarana yang meliputi alat berat sebanyak 108 unit.

Kota Denpasar dalam melakukan pengelolaan sampah sebagaimana dimaksudkan pada pasal 1 angka 25 Peraturan Daerah Kota Denpasar Nomor 3 Tahun 2015 Tentang Pengelolaan Sampah adalah "kegiatan yang sistematis, menyeluruh, dan berkesinambungan yang meliputi pengurangan dan penanganan sampah". Berdasarkan hasil wawancara dengan Bapak I Ketut Adi Wiguna, S.H., M.Si selaku Kepala Bidang Pengelolaan Sampah dan Limbah B3 DLHK kota Denpasar pada tanggal 09 Mei 2019 disebutkan bahwa pengurangan sampah di kota Denpasar pada saat ini yaitu tahun 2018 mencapai $18,5 \%$ sedangkan penanganan sampah mencapai $65 \%$. Pengurangan dan penanganan sampah di kota Denpasar dilakukan dengan adanya bank sampah, TPST 3R, TPS 3R, dan swakelola sampah dimasing-masing lingkungan/ dusun/ banjar/oleh desa/kelurahan dan desa pakraman setempat, tetapi masih ada saja sampah yang tidak terkelola yaitu dengan masih adanya pembuangan sampah di TPS-TPS liar.

\section{Desa Adat/Pakraman}

Menurut ilmu hukum adat, desa merupakan masyarakat hukum adat yang teratur, bersifat tetap, mempunyai kekuasaan sendiri, serta kekayaan sendiri berupa benda yang kelihatan dan tidak kelihatan mata (Ter Haar, 1960: 16).

Soepomo (1977:51) menyatakan bahwa "masyarakat hukum adat di Indonesia dapat dibagi atas 2 golongan menurut dasar susunannya, yaitu berdasarkan pertalian suatu keturunan (geneologi) dan yang berdasar lingkungan daerah (territorial)", Oleh karena itu, masyarakat hukum adat merupakan kesatuan masyarakat yang terikat oleh tatanan hukum adatnya sebagai persekutuan hukum berdasarkan kesamaan keturunan ataupun tempattinggal.

Menurut Suasthawa Dharmayuda (1999:2) "Desa Adat merupakan "kesatuan masyarakat Hukum Adat yang mempunyai satu kesatuan tradisi dan tata krama pergaulan hidup dalam ikatan Kahyangan Tiga Kahyangan Desa (tempat persembahyangan bersama), mempunyai wilayah tertentu, pengurus sendiri, mempunyai harta kekayaan sendiri yang berwujud maupun tidak berwujud, serta dapat mengatur rumah tangganya sendiri”".

Menurut Suasthawa Dharmayuda (2001:18) "Desa Pakraman diikuti oleh adat istiadat atau hukum adat yang tumbuh dan berkembang dalam lingkungan masyarakat setempat. Hukum adat yang dikenal dengan " $a w i g-$ awig" merupakan pedoman dasar dari desa pakraman dalam pemerintahannya. Awig-awig merupakan aturan yang dibuat oleh krama desa pakraman dan atau banjar pakraman yang dipakai sebagai pedoman dalam pelaksanaan $T r i$ Hita Karana sesuai dengan desa mawacara, desa kalapatra dan darma agama di desa 
pakraman atau banjar pakraman masingmasing".

Menurut Surpha (1993:31) bahwa desa adat (desa pakraman) merupakan wadah tempat hidup suburnya pengamalan ajaran-ajaran agama Hindu yang umumnya diwujudkan dalam pelaksanaan adat (kebiasaan) khususnya dalam bentuk upacara keagamaan Hindu dengan variasinya berwujud unsur-unsur budaya dan seni". Pasal 18B ayat (2) UUD 1945 disebutkan bahwa "Negara mengakui dan menghormati kesatuankesatuan masyarakat hukum adat beserta hak-hak tradisionalnya sepanjang masih hidup dan sesuai dengan perkembangan masyarakat dan prinsip Negara Kesatuan Republik Indonesia, yang diatur dalam undang-undang."

Pasal tersebut menjelaskan lembaga tradisional merupakan daerah yang bersifat istimewa karena mempunyai susunan asli berdasarkan hukum adat, di Bali ada perbedaan istilah antara desa adat dan desa pakraman, namun filosofis dan unsur-unsur desa adat dan desa pakraman itu adalah sama. Dalam penelitian ini, istilah desa yang digunakan adalah desa adat sesuai dengan berlakunya Perda terbaru yaitu Perda Provinsi Bali Nomor 4 Tahun 2019 Tentang Desa Adat di Bali.

Berdasarkan pasal 1 angka (8) Perda Provinsi Bali Nomor 4 Tahun 2019 Tentang Desa Adat di Bali disebutkan bahwa "Desa Adat adalah kesatuan masyarakat hukum adat di Bali yang memiliki wilayah, kedudukan, susunan asli, hakhak tradisional, harta kekayaan sendiri, tradisi, tata krama pergaulan hidup masyarakat secara turun temurun dalam ikatan tempat suci (kahyangan tiga atau kahyangan desa), tugas dan kewenangan serta hak mengatur dan mengurus rumah tangganya sendiri", sedangkan Pasal 5 menyebutkan bahwa "DesaAdat berstatus sebagai subyek hukum dalam sistem pemerintahan Provinsi Bali”.

Berdasarkan pengertian tersebut maka dapat disimpulkan bahwa desa adat merupakan kesatuan masyarakat hukum adat yang mempunyai satu kesatuan tradisi dan tata pergaulan hidup masyarakat umat Hindu dalam satu ikatan
Kahyangan Desa yang mempunyai tugas dan kewenangan dan berstatus sebagai subyek hukum dalam sistem pemerintahan Provinsi Bali, serta mempunyai hak mengatur dan mengurus rumah tangganya sendiri dengan membentuk suatu aturan hukumnya sendiri dan tunduk sendiri kepada aturan hukum yang dibuatnya.

\section{Peran serta desa adat dalam pengelolaan sampah di kota Denpasar}

Peranan desa adat/pakraman sangatlah penting karena desa pakraman merupakan kesatuan masyarakat hukum adat di Bali. Dilihat dari salah satu fungsinya desa adat membantu pemerintah daerah, dan pemerintah desa/ pemerintahan kelurahan dalam kelancaran dan pelaksanaan pembangunan di segala bidang serta menjaga, memelihara dan memanfaatkan kekayaan desa adat untuk kesejahteraan masyarakat desa adat (Suasthawa Dharmayuda (2001:20-21).

Salah satu wujud peran serta desa adat dalam menjaga, memelihara keasrian, dan kesucian wilayahnya adalah dengan peran serta desa adat dalam pengelolaan sampah. Peran serta desa adat dalam pengelolaan sampah sangat penting dan memberikan pengaruh besar, dimana pertama pengelolaan sampah dibawah pengelolaan desa adat dapat mempermudah jika terjadi permasalahan-permasalahan mengenai pengelolaan sampah, kerena secara khusus desa adat memiliki otonomi yang isinya dapat mengatur dan menyelesaikan permasalahan tersebut dalam ruang lingkup rumah tangga sendiri. Kedua dari segi pendanaan pengelolaan sampah desa adat memiliki ADD (Alokasi Dana Desa). Ketiga hal yang paling penting adalah desa adat memiliki kekuatan yang mengikat dan juga lebih mengetahui atau mengenal bagaimana keadaan dan kebiasaan masyarakatnya (krama desa) sendiri melalui tata pergaulan hidup masyarakat serta kesadaran hukum masyarakat dalam pengelolaan sampah, sehingga desa adat dapat melakukan pengawasan, pembinaan, dan penegakan hukum melalui pembentukan suatu aturan hukumnya sendiri berupa awig-awig atau perarem untuk mengatur hak dan kewajiban yang isinya bukan saja untuk 
masyarakat (krama desa) melainkan juga krama tamiu, tamiu, serta badan usaha yang berada dalam wilayah adat tersebut agar melakukan dan menaati aturan dalam pengelolaan sampah beserta larangan dan sanksinya, apalagi desa adat/ pakraman juga memiliki lembaga mitra kerja Prajuru Desa Adat yang melaksanakan fungsi penyelesaian perkara adat/wicara berdasarkan hukum adat yang berlaku di Desa Adat setempat yang disebut dengan Kerthadesa Desa Adat. Keempat penanganan masalah pengelolaan sampah dibawah pengelolaan desa adat dapat dilakukan secara berjenjang mulai dari tingkat banjar sampai di tingkat desa adat, sehingga permasalahan tersebut bisa diselesaikan di masingmasing banjar. Kelima dapat membuka lapangan pekerjaan bagi masyarakat (krama desa) yang ada.

Peran serta desa adat dalam pengelolaan sampah pada prinsipnya dapat mengunggah kesadaran bahwa segala perubahan yang terjadi di masyarakat hendaknya disikapi oleh desa adat. Dalam konteks ini, desa adat perlu membuka diri untuk lebih luas dan mendalam dalam berbagai permasalahan yang ada termasuk permasalahan sampah dalam pengelolaannya, karena sebagaimana dimaksud Pasal 22 huruf (j) Perda Provinsi Bali Nomor 4 Tahun 2019 Tentang Desa Adat di Bali mengenai Tugas Desa Adat dalam mewujudkan kasukretan sakala dan niskala adalah "Menjaga kesucian, kelestarian, kebersihan, dan ketertiban Palemahan Desa Adat", namun hal tersebut bukan saja menjadi tugas dan tangggung jawab desa adat saja melainkan juga masyarakat berdasarkan asas kebersamaan dan tanggung jawab dalam pengelolaan sampah, sebagaimana dimaksud juga pada Pasal 12 bahwa "Setiap orang yang berada atau bertempat tinggal di Palemahan DesaAdat wajib menjaga kesucian, kelestarian, kebersihan, dan ketertiban", berdasarkan konsep Tri Hita Karana dan Sad Kerthi.

Peran serta desa adat dalam pengelolaan sampah di kota Denpasar diatur dalam Peraturan Daerah Kota Denpasar Nomor 3 Tahun 2015 Tentang Pengelolaan Sampah sebagaimana dimaksud 36 ayat (1) yang berbunyi "desa pakraman dapat berperan serta dalam pengelolaan sampah", dilanjutkan pasal 36 ayat (2) huruf c yang berbunyi peran desa pakraman sebagaimana dimaksud ayat (1) adalah "melaksanakan pengelolaan sampah diwilayahnya secara mandiri dan/atau bekerjasama dengan pemerintah kota atau pihak lain" dan Peraturan Walikota Nomor 11 Tahun 2016 Tentang Tata Cara Pengelolaan dan Pembuangan Sampah di Kota Denpasar sebagaimana dimasksud pada pasal 3 ayat (1) yang berbunyi "masyarakat tidak diperbolehkan manaruh sampah di depan rumah, telajakan, dipinggir jalan, dan diatas trotoar"

Dasar hukum tersebut menjadikan desa adat memiliki ruang untuk melakukan pengelolaan sampah dari hulu maksudnya pengelolaan yang dilakukan sedekat mungkin dengan sumbernya, hal ini dilakukan agar pengurangan, penanganan, dan penegakan hukum terhadap pengelolaan sampah dapat berjalan disatuan terkecil masyarakat secara desentralisasi dengan tujuan bahwa pengelolaan sampah dapat diatur secara mandiri oleh desa adat melalui pengawasan dan pembinaan secara efektif dan efesien namun tetap berkordinasi dengan DLHK Kota Denpasar sebagai instansi yang berwenang dalam pengelolaaan sampah.

Dipilihnya pengelolaan sampah dari hulu yang tujuannya sedekat mungkin dengan sumbernya secara desentralisasi melalui desa adat adalah karena jika dilakukan dengan sentarlisasi atau terpusat maka pengelolaan sampah membutuhkan lahan yang luas, transportasi yang banyak, dan biaya yang tinggi.

Selain hal tersebut, pengelolaan sampah oleh desa adat juga didukung dan dilatarbelakangi oleh sistem pengelolaan sampah kota Denpasar yaitu PESAN MAMA (Sistem Pengelolaan Sampah Secara Mandiri Berbasis Masyarakat) dengan asas pengelolaan sampah, manajemen pengelolaan sampah, dan paradigma baru dalam pengelolaan sampah secara berkelanjutan yang juga memberikan ruang kepada desa adat untuk berperan serta dalam pengelolaan sampah dalam ruang lingkup lebih kecil lagi yaitu berbasis keluarga dengan tujuan sampah dapat dipilah sesuai jenisnya 
dari ruang lingkup keluarga atau rumah sendiri, sehingga sampah yang masuk ke hilir atau TPA dapat berkurang dan hanya meninggalkan residunya saja.

Dalam upaya pemberdayaan dan pengayoman desa adat sebagai salah satu lembaga adat, perlu dijaga otonomi desa adat, Pemerintah Daerah dalam pemerdayaan. Desa adat dapat mengambil peran sebagai fasilitator yaitu membantu memberikan fasilitas salah satunya fasilitas dalam menjaga palemahan yakni mengawasi serta menjaga kesucian, kelestarian, kebersihan, dan ketertiban wilayah desa adat melalui pengelolaam sampah.

Adapun program dan fasilitas yang diterapkan untuk mendukung peran serta desa adat dalam melakukan pengelolaan sampah di kota Denpasar sebagaimana dimaksud pada penjelasan diatas, dimana untuk melakukan pengurangan dan penanganan sampah berbasis keluarga yaitu dari hulu yang dilakukan sedekat mungkin dengan sumbernya melalui pengawasan, pembinaan, dan penegakan hukum oleh desa adat adalah sebagai berikut:

\section{A. Swakelola Sampah}

Keberadaan swakelola sampah diterapkan atas dasar hukum yaitu pertama Peraturan Daerah Kota Denpasar Nomor 3 Tahun 2015 Tentang Pengelolaan Sampah sebagaimana dimaksud 36 ayat (1) yang berbunyi "desa pakraman dapat berperan serta dalam pengelolaan sampah", dilanjutkan pasal 36 ayat (2) huruf c yang berbunyi peran desa pakraman sebagaimana dimaksud ayat (1) adalah "melaksanakan pengelolaan sampah diwilayahnya secara mandiri dan/atau bekerjasama dengan pemerinyah kota atau pihak lain". Kedua peraturan pelaksananya yaitu adanya Peraturan Walikota Nomor 35 Tahun 2006 Tentang Pelaksanaan Kelompok Swakelola Kebersihan di Kota Denpasar sebagaimana dimaksud pasal 1 ayat (1) yang berbunyi "desa/ kelurahan/ banjar adat/dusun/ lingkungan, dan kelompok masyarakat dapat melaksanakan pengelolaan sampah secara swakelola". Ketiga Peraturan Walikota Nomor 11 Tahun 2016 Tentang Tata Cara Pengelolaan dan Pembuangan
Sampah di Kota Denpasar sebagaimana dimasksud pada pasal 3 ayat (1) yang berbunyi "masyarakat tidak diperbolehkan manaruh sampah di depan rumah, telajakan, dipinggir jalan, dan diatas trotoar" melainkan harus mengikuti program swakelola sampah di lingkungan/dusun/banjar di desa pakraman masing-masing".

Swakelola sampah merupakan pihak ketiga yang melayani pengangkutan sampah rumah tangga dari rumah ke rumah dan diangkut serta dibuang ke TPS-TPS terdekat. Tujuan adanya swakelola sampah untuk pemberdayaan masyarakat mengolah sampah di tingkat rumah tangga sehingga lingkungan menjadi bersih dengan dampak yang diinginkan adalah bagi masyarakat terbukanya lapangan pekerjaan, kesehatan masyarakat meningkat karena lingkungan menjadi bersih.

Pada saat ini swakelola sampah di kota Denpasar sebanyak 171 yang terdiri dari swakelola sampah desa/ kelurahan/ banjar adat/ dusun/ lingkungan, dan kelompok masyarakat. Kota Denpasar yang terdiri dari 4 kecamatan, pada saat ini memiliki 43 desa/kelurahan dengan rincian 27 desa dinas dan 16 kelurahan. Dari 43 desa dinas/kelurahan tersebut ada sebanyak 23 desa/ kelurahan yang belum mempunyai swakelola sampah dengan rincian 15 desa dan 8 kelurahan.

Berdasarkan data tersebut menunjukan bahwasannya sebagian besar desa/kelurahan masih belum mempuyai swakelola sampah, namun pemerintah kota Denpasar terus berjuang agar semua desa/kelurahan mempunyai swakelola sampah. Desa/kelurahan yang saat ini belum mempunyai swakelola sampah dibantu oleh pemerintah kota Denpasar dengan menyediakan kontainer dimasing-masing desa/kelurahan.

Berdasarkan hasil wawancara dengan Bapak I Made Murah, S.sos.,M.Ap selaku kordinator TPST kota Denpasar dan ketua bank sampah kota Denpasar yang ditemui di Gedung Swaka Dharma tepatnya di UPT Pengelolaan Sampah Kota Denpasar pada tanggal 02 Mei 2019 disebutkan bahwa keberadaan swakelola sekarang belum mampu memecahkan permasalahan sampah di kota Denpasar melainkan hanya memindahkan masalah. 
Berdasarkan uraian diatas berjalannya pengelolaan sampah melalui swakelola sampah yang memberikan ruang kepada desa/kelurahan/ desa adat yang di kota Denpasar untuk berperan serta dalam pengelolaan sampah dalam ruang lingkup lebih kecil lagi yaitu berbasis keluarga, sampai saat ini belum berjalan efektif dan dikatakan belum dapat memecahkan permasalahan sampah di kota Denpasar adalah karena 1). Belum semua desa/kelurahan/desa adat di kota Denpasar mempunyai swakelola sampah. 2). Belum semua desa adat yang ada di kota Denpasar memiliki aturan dalam bentuk awig-awig atau perarem yang secara khusus mengatur hak dan kewajiban masyarakat (krama desa, krama tamiu, tamiu, serta badan usaha yang berada dalam wilayah desa adat tersebut) untuk melakukan pengelolaan sampah dan mewajibkan memilah sampah sesuai jenisnya dalam ruang ruang lingkup keluarga atau rumah tangga sendiri dan mengatur larangan beserta sanksi bagi yang membuang atau membakar sampah secara sembarangan, 3). Belum adanya sarana dan prasana pengangkut sampah (moci) sesuai dengan jenis sampah di setiap desa adat, dan 4). Masih rendahnya kesadaran masyarakat kota Denpasar dalam pengelolaan sampah, hal ini dapat dilihat dari masih banyaknya masyarakat kota Denpasar tidak memilah sampah sesuai jenisnya dari ruang lingkup keluarga atau rumah tangga, sehingga sampah yang diangkut oleh swakelola sampah adalah sampah dengan kondisi tercampur, kemudian masih banyaknya masyarakat kota Denpasar yang tidak mengikuti aturan baru untuk ikut swakelola sampah, masih banyak masyarakat kota Denpasar yang menaruh sampah di depan rumah, telajakan, dipinggir jalan, dan diatas trotoar, serta masih banyak masyarakat kota Denpasar yang membuang atau membakar sampah secara sembarangan, sehingga tidak memberikan suatu perubahan yang besar dalam pengelolaan sampah di kota Denpasar dibawah pengelolaan desa/kelurahan/desa adat.

\section{B. TPST 3R dan TPS 3R}

TPST 3R sebagaimana dimaksud Pasal 1 angka 18 Peraturan Daerah Kota Denpasar Nomor 3 Tahun 2015 Tentang Pengelolaan sampah merupakan "Tempat pengolahan sampah terpadu yaitu tempat dilaksanakannya kegiatan pengumpulan, pemilahan, penggunaan ulang, pendauran ulang, pengolahan, dan pemrosesan akhir sampah", sedangkan TPS 3R sebagaimana dimaksud pada Pasal 1 angka 7 Peraturan Pemerintah Republik Indonesia Nomor 81 Tahun 2012 Tentang Pengelolaan Sampah Rumah Tangga dan Sampah Sejenis Sampah Rumah Tangga adalah "Tempat Pengolahan sampah dengan prinsip 3R yaitu reduce (mengurangi), reuse (menggunakan kembali), dan recycle (daur ulang) yaitu tempat dilaksanakannya kegiatan, pengumpulan, pemilahan, penggunaan ulang, dan pendauran ulang skala kawasan".

Keberadaan TPST 3R dan TPS 3R khususnya di desa adat diibaratkan sebagai lilin kecil dalam pengelolaan sampah di kota Denpasar yang diharapkan dapat menciptakan lilin-lilin lainnya dalam pengelolaan sampah di kota Denpasar.

Pada saat ini Kota Denpasar hanya memiliki 1 TPST 3R yaitu di TPST 3R Kertalangu Kesiman, dan 6 TPS 3R yang terdiri dari TPS 3R Monang-maning, TPS 3R Sari Sedana Bung Tomo, TPS 3R Cemara di Sanur Kaja, TPS 3R Sekar Tanjung di Sanur Kauh, TPS 3R Pegok, dan TPS 3R Palasari. Sedikitnya keberadaan TPST 3R dan TPS 3R di kota Denpasar karena desa/kelurahan di kota Denpasar tidak semua memiliki lahan untuk membangun TPST 3R dan TPS 3R.

Volume sampah perhari TPST 3R Kesiman Kertalangu adalah $1 \mathrm{~m}^{3}$ dengan armada untuk mengangkut yaitu sebanyak 1 truk sedangkan TPS 3R yang terbanyak menghasilkan volume sampah adalah TPS 3R Monang-maning dengan volume sampah perhari yaitu $96 \mathrm{~m}^{3}$ dengan armada untuk mengangkut yaitu sebanyak 16 truk kemudian untuk TPS 3R yang terendah menghasilkan volume sampah adalah TPS 3R Palasari dan TPS 3R Sari Sedana Bung Tomo dengan volume sampah perhari yaitu $12 \mathrm{~m}^{3}$ dengan armada untuk mengangkut yaitu sebanyak 2 truk. Dari 1 TPST dan 6 TPS 3R yang ada di kota Denpasar baru ada 4 TPS 3R yang dibawah pengelolaan desa yaitu Desa Sanur Kauh (TPS 3R Sekar Tanjung, TPS 3R Palasari), Desa Sanur 
Kaja (TPS 3R Cemara), dan Desa Pemucutan Kaja (TPS 3R Sari Sedana Bung Tomo), namun walaupun pengelolaannya sudah berada dibawah desa tetapi residu yang masuk ke kontainer masih diambil alih oleh DLHK kota Denpasar untuk pengangkutan menuju ke TPA (Tempat Pemrosesan Akhir), sedangkan 1 TPST 3R, 2 TPS 3R, dan 13 TPS yang tersebar di desa masih berada dibawah pengelolaan DLHK Kota Denpasar.

Berdasarkan hasil penelitian tersebut dapat disimpulkan bahwa berjalannya sistem pengelolaan sampah secara mandiri berbasis masyarakat dengan adanya TPST 3R dan TPS 3R belum berjalan efektif dan menyeluruh dikarenakan 1) Belum semua TPST 3R dan TPS 3R yang ada di kota Denpasar berada pada pengelolaan desa adat, 2) Pengelolaan belum sepenuhnya dilakukan oleh desa adat karena residu masih diangkut atau diambil alih oleh DLHK Kota Denpasar, 3) Masih sedikitnya keberadaan TPST 3R dan TPS 3R di kota Denpasar dikarenakan tidak semua desa/kelurahan/desa adat di kota Denpasar memiliki lahan untuk membangun TPST 3R dan TPS 3R sehinga pengelolaan sampah hanya terjadi pada wilayah yang memiliki TPST 3R dan TPS 3R sedangkan wilayah yang hanya terdapat TPS pengelolaan sampah tidak terjadi.

\section{Bank Sampah}

Bank sampah dilaksanakan sebagai salah satu program pemerintah kota Denpasar yang sejalan dengan paradigma baru pengelolaan sampah dan sistem pengelolaan secara mandiri dan berbasis masyarakat dengan tujuan sebagai salah satu stimulan untuk meningkatkan kesadaran masyarakat tentang pentingnya pengelolaan dan pendayagunaan sampah. Bank sampah berdasarkan pasal 1 ayat (2) Peraturan Menteri Negara Lingkungan Hidup Nomor 13 Tahun 2012 Tentang Pedoman Pelaksanaan Reduce, Reuse, dan Recycle Melalui Bank Sampah berbunyi "bank sampah adalah tempat pemilahan dan pengumpulan sampah yang dapat didaur ulang dan/atau diguna ulang yang memiliki nilai ekonomi”.
Bank sampah di kota Denpasar pada tahun 2018 mencapai 100 bank sampah dan pada tahun 2019 ditargetkan kota Denpasar memiliki 200 Bank sampah. Dari 100 bank sampah yang ada sekarang, 32 merupakan bank sampah binaan dari DLHK kota Denpasar, 4 bank sampah dikelola oleh desa yaitu bank sampah Jaya Lestari desa Pemogan, bank sampah Jempiring desa Penatih, bank sampah Sumerta Kelod desa Sumerta Kelod, dan bank sampah Yang Batu desa Dangin Puri, Sedangkan 64 Bank sampah merupakan bank sampah swasta yang dikelola oleh kelompok masyarakat atau pribadi yang berdiri sendiri. 100 bank sampah tersebut mampu menghasilkan 16 ton sampah anorganik setiap bulannya. Sedangkan keberadaan bank sampah sekolah di kota Denpasar sudah mencapai 28 sekolah dengan rincian 3 TK, 20 SD, 4 SMP, dan 1 SMA.

Berdasarkan hasil penelitian dapat disimpulkan bahwa berjalannya bank sampah dibawah pengelolaan desa adat di kota Denpasar belum berjalan efektif karena 1). Masih minimnya bank sampah yang ada di desa adat kota Denpasar maupun di sekolah, 2). Belum adanya standarisasi harga barang, sehingga menyebabkan banyak bank sampah yang tidak aktif karena nilai beli dan jual yang jauh, 3). Tidak adanya lagi reward dan punishment terhadap bank sampah yang ada di kota Denpasar, padahal reward dan punishment sangat penting untuk memotivasi kinerja dari bank sampah agar berkualitas dan bertanggung jawab dengan tugas yang diberikan.

\section{PENUTUP \\ 1. Kesimpulan}

Peran serta desa adat dalam pengelolaan sampah di Kota Denpasar belum berjalan efektif karena 1) Belum semua atau masih sedikitnya keberadaan fasiltas pengelolaan sampah seperti swakelola sampah, TPST 3R, TPS 3R, dan Bank Sampah yang dimiliki dan berada dibawah pengelolaan desa adat, 2) Masih rendahnya kesadaran masyarakat kota Denpasar untuk melakukan pengelolaan sampah dari ruang lingkup keluarga atau rumah tangga sendiri, 3) Belum semua desa adat yang ada di kota Denpasar memiliki 
aturan dalam bentuk awig-awig atau perarem yang secara khusus mengatur hak dan kewajiban masyarakat (krama desa, krama tamiu, tamiu, serta badan usaha yang berada dalam wilayah desa adat tersebut) untuk melakukan pengelolaan sampah dan mewajibkan memilah sampah sesuai jenisnya dalam ruang ruang lingkup keluarga atau rumah tangga sendiri dan mengatur larangan beserta sanksi bagi yang membuang atau membakar sampah secara sembarangan, 4) Kurangnya pelaksanaan pengelolaan sampah yang diwujudkan melalui sosialisasi ke setiap banjar.

\section{Saran}

Diharapkan bahwa peran serta Desa Adat dalam pengelolaan sampah di Kota Denpasar meliputi pengurangan dan penanganan sampah berbasis keluarga yaitu dari hulu yang dilakukan sedekat mungkin dengan sumbernya melalui pengawasan, pembinaan, dan penegakan hukum dapat berjalan efektif, hal ini dapat terjadi jika 1) Makin banyaknya keberadaan fasiltas pengelolaan sampah seperti swakelola sampah, TPST 3R, TPS 3R, dan Bank Sampah yang dimiliki dan berada dibawah pengelolaan desa adat, 2) Meningkatnya kesadaran masyarakat kota Denpasar untuk melakukan pengelolaan sampah dari ruang lingkup keluarga atau rumah tangga sendiri, 3 Adanya suatu aturan yang mengikat di desa adat yang ada di kota Denpasar dalam bentuk awig-awig atau perarem yang secara khusus mengatur hak dan kewajiban masyarakat (krama desa, krama tamiu, tamiu, serta badan usaha yang berada dalam wilayah desa adat tersebut) untuk melakukan pengelolaan sampah dan mewajibkan memilah sampah sesuai jenisnya dalam ruang ruang lingkup keluarga atau rumah tangga sendiri dan mengatur larangan beserta sanksi bagi yang membuang atau membakar sampah secara sembarangan, 4) Adanya pelaksanaan pengelolaan sampah yang diwujudkan melalui sosialisasi yang berkelanjutan ke setiap banjar.

\section{DAFTAR PUSTAKA}

\section{Buku-buku}

Dharmayuda, I Made Suasthawa, 1999, Memperdayakan Desa Pakraman Dipandanag Dari Sudut Filsafat Dan Agama, Lembaga Pengkajian Budaya Bali, Denpasar

Dharmayuda, I Made Suasthawa, 2001, Desa Adat Kesatuan Masyarakat Hukum Adat di Propinsi Bali, Denpasar, PT Upada sastra

Kamus Besar Bahasa Indonesia (KBBI), 2008, Jakarta, Pusat Bahasa Departemen Pendidikan Nasional.

Narbuko, Cholid, dan Abu Achmadi, 2003, Metodologi Penelitian, Jakarta, PT. Bumi Aksara.

Ter Haar, B. Bzn, 1960, Asas-asas dan Susunan Hukum Adat (Beginselen en Atelsel vab Het Adatrecht), terjemahan K. Mg. Soebakti Poesponoto, Jakarta: Pradnya Paramita.

Sucipto, Cecep Dani, 2012, Teknologi Pengolahan Daur Ulang Sampah, Publishing, Yogyakarta.

Soekanto, Soerjono, 2012, Pengantar Penelitian Hukum cet Ketiga, Jakarta, UI Press.

Soepomo.1977, Bab-Bab Tentang Hukum Adat, Pradnya Paramitha, Jakarta

Surpha, I Wayan. 1993, Eksisstensi Desa Adat di Bali, Denpasar, PT Upada sastra

\section{Peraturan Perundang-undangan}

Undang-Undang Dasar Replubik Indonesia Tahun 1945

Peraturan Menteri Negara Lingkungan Hidup Nomor 13 Tahun 2012 Tentang Pedoman Pelaksanaan Reduce, Reuse, dan Recycle Melalui Bank Sampah.

Peraturan Daerah Kota Denpasar Nomor 3 Tahun 2015 Tentang Pengelolaan Sampah.

Peraturan Daerah Provinsi Bali Nomor 4 Tahun 2019 Tentang Desa Adat di Bali.

Peraturan Walikota Nomor 35 Tahun 2006 Tentang Pelaksanaan Kelompok Swakelola Kebersihan di Kota Denpasar.

Peraturan Walikota Nomor 11 Tahun 2016 Tentang Tata Cara Pengelolaan dan Pembuangan Sampah di Kota Denpasar. 